\title{
Campaign Video Usage in Preventing Cervical Cancer among Female Students
}

\author{
Imam Nuraryo \\ imam@kwikkiangie.ac.id \\ Institut Bisnis dan Informatika Kwik Kian Gie
}

\begin{abstract}
Cervical cancer prevention campaign video contains information ranging from understanding, the symptoms caused to how to avoid cervical cancer. This campaign video is one way to educate the public about the importance of knowing cervical cancer. The purpose of this study was to find out how effective a cervical cancer prevention campaign video on knowledge attitude and intend to behavior among female students. The theory used is Planned Behavior theory which is the result of the refinement of the reasoned action theory developed by Ajzen and Fishbein (1980). The method used is quantitative with the experimental methods. This study used an experimental pre-post-post-test static group design. It could estimate the equivalence of the two groups and have the opportunity to correct differences that have arisen before the event. It must have access to groups before and after events. The controlled group and the experiment group consisted of 15 people per each group. The research data obtained from the questionnaires were processed and analyzed using independent samples t-test. The technique of collecting data by spreading the questionnaire which was distributed into a couple of groups. The result of this research is campaign video does not give a significant effect on knowledge, attitude and behavioral intention of female students neither in the controlled groups nor in experiment group.
\end{abstract}

Keywords: Campaign; Video; Preventing; Cervical Cancer; Female Students

\section{INTRODUCTION}

Cervical cancer or commonly referred to as uterine cancer is cancer that grows on cells in the cervix, which is cancer that occurs in the uterine cervix, a part of the female reproductive organs that is the entrance to the uterus that lies between the uterus and the intercourse. The journey from HPV infection, pre-cancerous stage to cervical cancer takes 10 to 20 years. This cancer attacks many women and the number of cancer sufferers is increasing every year. This cancer usually grows and spreads in developing countries. Of all cancer sufferers in Indonesia, almost one third are cervical cancer sufferers. This cancer is indeed a scary type of disease that can even kill its sufferers. In Indonesia alone, one woman dies from cervical cancer every hour

World Health Organization (WHO) revealed that this infection is a major risk factor for cervical cancer. Every year, hundreds of thousands of cases of HPV are diagnosed in the world and thousands of women die of cervical cancer, which is caused by the infection. With the danger of this disease, various preventive and treatment measures have also been made to overcome this cervical cancer (Cohen et al, 2019).

WHO estimates that in 2030 there will be an increase in cervical cancer sufferers in Indonesia, even up to seven times from now. This, as seen from cervical cancer sufferers from 2000 to 2012, attacks more young people aged 21-22 years. The results of research conducted by WHO also show that Indonesia is the country with the least cancer screening 
measures carried out. More than 92 thousand cases of cancer deaths occurred in women in Indonesia in 2014. A total of 10.3 percent is the number of deaths caused by cancer (Ministry of Health of the Republic of Indonesia, 2019).

Indonesia is one of the countries where the population is the highest cervical cancer sufferer in the world. It is estimated that there are 15,000 new cases of cervical cancer occur each year, while the mortality rate is estimated at 7,500 cases per year. According to data from the Indonesian Cancer Foundation (YKI), this disease has claimed more than 250,000 women in the world and there are more than 15,000 new cases of cervical cancer, which approximately 8,000 deaths in Indonesia each year.

In developing countries, including Indonesia, cervical cancer ranks number one as a cancer that attacks women. As for the world rank, this cancer ranks second. Data quoted from the World Health Organization (WHO) shows that there are 493,243 people per year suffering from cervical cancer in the world with 273,505 deaths per year in cancer (Susanti et al, 2017).

The cause of cervical cancer on average is caused by infection with the Human Papilloma Virus (HPV). The types of HPV that cause cervical cancer are HPVs 16 and 18. These types of HPV can shorten the time period between infection and progression to neoplasia (the formation or presence of a new, abnormal growth of tissue) from a matter of years to months. Viral infections will become more virulent if a person's immunity decreases. Symptoms are not very visible at an early stage, which is why cervical cancer that starts from HPV infection is considered "The Silent Killer" (Ngoma and Autier, 2019).

Meanwhile, risk factors for cervical cancer can be caused by sexual relations at an early age ( $<20$ years), multiple sexual partners, smoking, use of birth control pills, chronic trauma to the cervix uteri and genital (something that relating to the human or animal reproductive organs) hygiene. More than half of cervical cancer sufferers are in advanced stages that require special facilities for treatment such as radio therapy equipment that is only available in some big cities (KICKS, 2017).

The Indonesian Cancer Foundation (YKI) together with the Indonesian Coalition to Prevent Cervical Cancer (KICKS) promotes promotive and preventive campaigns to prevent cervical cancer effectively. Promotive action, for example, is done by providing education. Meanwhile, preventive measures carried out by means of HPV vaccination and pap smear examination are effective ways to prevent cervical cancer (Ratnasari, 2017).

The purpose of this study is to find out how effective cervical cancer prevention videos are towards knowledge, attitudes and behavioral tendencies among Communication Studies students at one of the public universities in Jakarta.

\section{LITERATURE REVIEW}

Some previous research states that the use of video is also used to increase knowledge and awareness to maintain the reproductive organs. Jenkins et al (1999) state that the use of extension videos has encouraged experimental groups to conduct serious health checks on their reproductive organs. This research was conducted on a group of ethnic Vietnamese women living in the United States (Jenkins et al, 1999).

Love et al (2009) found that the use of video with message content using a local cultural approach proved effective in influencing participants in conducting Pap tests to 
examine their uterus. This research was conducted among women from Thailand. The video used in this experimental study is in the form of soap opera format, starring actors from Thailand (Love et al, 2009).

The grand theory used in this research is structural functional theory. Structural theory was introduced by Parson, he revealed that structural theory is the most influential theory in social science in the current century, so that it can be synonymous with sociology. The basic concept of this theory views social reality as the relations of community systems, which are in equilibrium, that is, the unity consisting of interdependent parts, so that a change in one part is seen to cause another change in the system.

There are four absolute requirements that must be in place to include the community to function. The four requirements are called AGIL. AGIL stands for Adaption, Goal Attention, Integration, and Latency. This theory can function as a theory, so it must contain four absolute conditions that must exist. The four requirements are referred to by Parson as AGIL (Adaption, Goal Attention, Integration, and Latency).

Functional structural theory is often regarded as a theory that is anti-social change. That is because this theory exalts structure dominance and is reluctant to make room for conflict. Parsons himself considers social change as both troublesome and dangerous to system imperatives. However, Parsons' thinking is still relevant to the study of social change (Kuswandoro, 2015).

The second middle range theory in this study is Theory of Reasoned Action (TRA). This theory is a theory which states that the decision to conduct a particular behavior is the result of a rational process in which the choice of behavior is considered, the consequences and the results of each behavior are evaluated and a decision has been made, whether to behave in a certain manner or not. Then this decision is reflected in the purpose of behavior, which is very influential on the behavior that appears.

This theory was coined by Fishbein and Ajzen in the year 1975 which came from a previous study known as the theory of attitude, where the theory was used as a reference for the study of attitudes and behavior. This theory presents a framework for more emphasis on cognitive processes. In addition, this theory also assumes that humans are creatures with the potential for reasoning in deciding what behavior to take, which systematically utilizes the information available around it.

This theory is very closely related to the attitudes and behavior of individuals in carrying out activities. For example, someone will donate blood on the grounds that it will produce benefits for themselves and their environment. In addition, this theory assumes that humans are beings who are able to act on their own accord and plan what they will do.

Applied theory used in this study is Theory of Planned Behavior (TPB). This theory was developed by Ajzen. Ajzen is the person who perfects Theory of Reasoned Action (TRA) put forward by Ajzen and Fishbein (1980). Theory of Planned Behavior is basically the same as the theory of reasoned action that is the intention of individuals to perform certain behaviors, the intention is considered to be able to see motivational factors that influence behavior (Wahyono, 2014). 


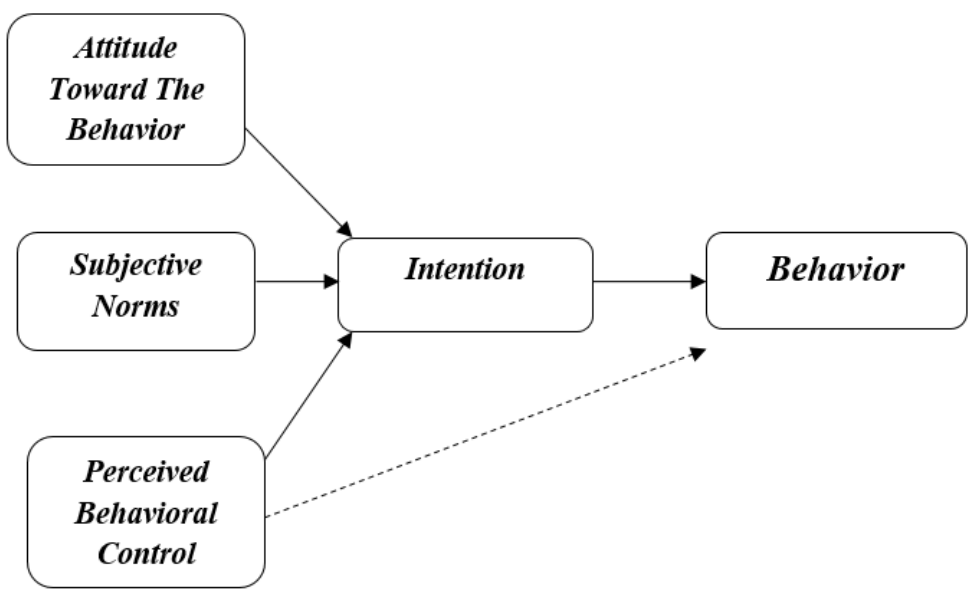

Figure 1. Theory of Planed Behavior

From figure 1 explained that attitude towards the behavior is also called attitude. Ajzen and Fishbein (1980) argues that attitudes toward behavior are determined by beliefs about the consequences of a behavior or briefly called behavioral beliefs. The main focus of the theory of planned behavior is the intention of individuals to perform certain behaviors, the intention is considered to be able to see motivational factors that influence behavior. Intention is an indication of how hard people want to try and how much effort will be spent by individuals to carry out a behavior.

Confidence relates to an individual's subjective assessment of the world around him, an individual's understanding of himself and his environment, carried out by connecting certain behaviors with various benefits or losses that might be obtained if the individual does or does not do it. This belief can strengthen attitudes toward the behavior if based on evaluations conducted by individuals, obtained data that the behavior can provide benefits for him.

Subjective Norm is also called subjective norm. Subjective norms are individual perceptions of the expectations of people who influence in their lives (significant others) regarding whether or not certain behaviors do or don't. This perception is subjective, so this dimension is called subjective norms. As with attitudes toward behavior, subjective norms are also influenced by beliefs.

The difference is that if attitudes toward behavior are a function of individual beliefs about behavior that will be carried out (behavioral belief), then subjective norms are functions of individual beliefs obtained from the views of others towards the object of attitudes associated with individuals (normative beliefs).

Perceived behavioral control is also called perception of behavioral control. Behavioral control perception or can be called behavioral control is the individual's perception of the ease or difficulty of realizing a particular behavior. To explain the perception of this behavioral control, Ajzen distinguishes it from the locus of control.

The center of control is related to individual beliefs that are relatively stable in all situations. Behavioral control perception can change depending on the situation and type of 
behavior to be performed. The center of control is related to an individual's beliefs about his success in doing everything, whether it depends on his own efforts or other factors outside himself.

Intention is an indication of how hard people are trying to try and how much effort will be spent by individuals to carry out a behavior. In TRA, it is explained that a person's intention towards behavior is formed by two main factors, namely attitude toward the behavior and subjective norms, while in TPB one factor is added, namely perceived behavioral control. Perceived behavioral control is an individual's perception of the control he has in connection with certain behaviors. According to Ajzen and Fishbein (1980), this factor refers to individual perceptions about the ease or difficulty of eliciting certain behaviors and is assumed to be a reflection of past experiences and also anticipated obstacles (Becker and Gibson, 1998).

Meanwhile, understanding the campaign is a goal oriented communication activity. Campaign activities always have a goal to be achieved. The achievement of these goals certainly cannot be done through random actions, but must be based on the systematic and strategic organization of actions (Morisan, 2014). Public relations campaign in the narrow sense aims to increase the awareness and knowledge of the target audience to grab attention and foster positive perceptions or opinions on an activity of an institution or organization (corporate activities) in order to create a trust and image that both from the community through the intensive delivery of messages with a process of communication and a certain period of time that is sustainable.

All actions in the campaign must always be monitored so as not to leave the designated zone. In practice there will be many obstacles faced to make campaign actions on the right track. Therefore, it must be understood that campaign actions are not rigid and partial actions, but are adaptive, anticipatory, integrative and oriented towards problem solving (Mulyana, 2005). A campaign as an organized behavior, must be planned and implemented systematically and carefully. This shows that campaign activities require management touch, namely the ability to design, implement, control and evaluate a program of activities in a rational, realistic, efficient and effective manner.

Management practices in campaign activities are not new. From the start, campaign activities always cover the stages of planning, implementation to evaluation. The difference is that at present these various stages are standardized and formalized in terms of campaign management, which is the process of managing campaign activities effectively and efficiently by utilizing all available resources to achieve the stated goals. With the inclusion of managerial elements in campaign management it is expected that the chances of success in achieving campaign objectives will be more open and greater.

Benefits of Public Relations Campaigns are: (1) increasing the awareness and knowledge of the target audience of the existence of an organization, (2) grabbing attention and fostering positive perceptions or opinions on an organization or company's activities (corporate activities) in order to create a trust and a good image of the community, (3) provide continuous illumination, understanding and motivate the community towards a particular activity or program.

The elements contained in a campaign are (1) the existence of an activity or communication process that is designed in such a way in a certain period of time, (2) the communicator or person who conveys a message to be conveyed to another party, (3) the 
communicant or the the recipient of the message will be motivated to do something with pleasure as a result of the communication activities carried out by the communicator, (4) symbolic interactions where there is a transfer of symbols or symbols of communication that have a certain meaning.

Campaign activities are programmed and well planned, then all actions in the campaign must be monitored so that they do not go out of the direction set. In practice there will be many obstacles faced to make campaign actions on the right track. For this reason, it must be understood that campaign actions are not rigid and partial actions, but are adaptive, anticipatory, integrative and problem-oriented.

Campaign video is a form of communication activity that can be used to persuade or persuade by providing continuous knowledge to the target audience. In this study, researchers wanted to see the effectiveness of the cervical cancer prevention video campaign on knowledge and attitudes among female students.

As for someone who has cervical cancer or someone infected with HPV is invisible and not easily observed. The easiest way to find out is by doing a cervical cytological examination. Currently, such an examination is very popular with the name Pap-smear or Papanicolaou smear taken from the name of the Greek doctor who discovered this method, namely George N. Papanicolaou. Pap smears can identify cervical cancer seeds, where treatment can prevent the cervical cancer.

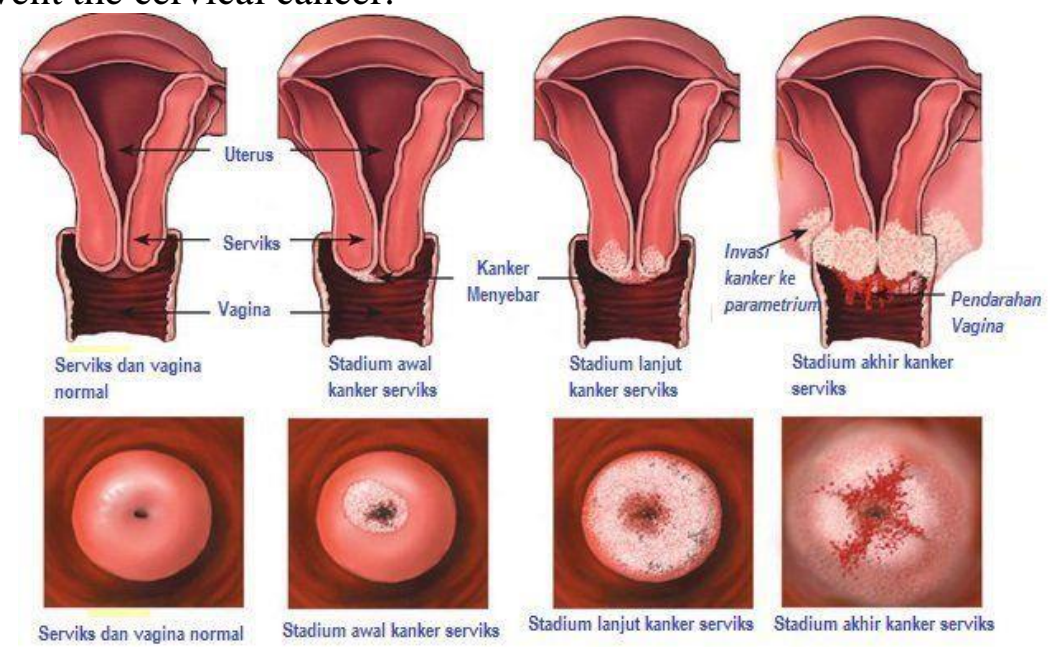

Figure 2. Cervical Cancer Process (Source : “The second highest case of cervical cancer in the world", 2017)

In addition to cervical cytological methods, there are also various other methods for early detection of HPV infection and cervical cancer, for example, IVA (Visual Inspection with Acetic Acid), and Colposcopy. Basically all types of treatment are carried out with the aim to kill cells that contain the HPV virus. Another method that can be used is to get rid of damaged or infected parts by electric surgery, laser surgery, or cryosurgery (removing abnormal tissue by freezing) (Ngoma and Autier, 2019). The hypotheses of this study are as follows; 
Hypothesis 1: Video of cervical cancer campaign has a significant effect on the knowledge of the female students.

Hypothesis 2: Video of cervical cancer campaign has a significant effect on the attitude of the female students.

Hypothesis 3: Video of cervical cancer campaign has a significant effect on the tendency of students to behave.

\section{RESEARCH METHOD}

The method used in this research is quantitative research methods. Rakhmat and Ibrahim (2017), revealed that experimental research is to examine the causal relationship by manipulating one or more variables in one (or more) experimental group, and comparing the results with a control group that did not undergo manipulation. Manipulation here means systematically changing values of the independent variable. After being manipulated, the independent variable is usually called "Experimental treatment". This study uses a pre-postpost static group design. Researchers can estimate the equivalence of the two groups and have the opportunity to correct differences that have arisen before the event. It must have access to groups before and after events.

The respondents in this research were a female student group at one of the private universities in North Jakarta. The age of the respondent is 19-23 years old. The total number of female students studied was 30 female students. The number is divided into two groups, the experimental group and the control group. The respondents were studying in communication science study program. Data analysis used in this research were t-test. This statistic (t-Test) is intended to see the significance of the influence of the independent variables individually on the dependent variable, assuming the other independent variables are constant.

The $\mathrm{t}$-Test $\mathrm{t}$ is intended to see the significance of the influence of individual independent variables on the dependent variable, assuming the other independent variables are constant. The hypothesis in this test is:

$\mathrm{H} 0: \beta \mathrm{i}=0$ (means that there is no significant effect between the independent variables on the dependent variable).

Ha: $\beta \mathrm{i}>0$ (means there is a significant influence between the independent variables on the dependent variable).

Where, $\beta$ is the coefficient of the 1 st independent variable and constant, while $\beta$ is the value of the hypothesis parameter. Usually $\beta$ (regression coefficient or determination) is considered equal to zero or there is no influence between the independent variables on the dependent variable. Terms of acceptance or rejection of the H0 hypothesis are as follows:

Reject H0 if Sig (One tailed) $<0.05$

Reject Ha if Sig (One tailed) $\geq 0.05$ 


\section{RESULTS AND DISCUSSION}

This study uses 20 respondents as a validity and reliability test. To measure the variables to be investigated, in the initial stages the researcher conducted a questionnaire test of the statements that had been prepared. The pre-questionnaire represented variables such as knowledge and attitudes towards the video campaign. A variable is said to be valid, if the result of $r$ value is greater than $r$ table ( $r$ count $>r$ table). While a variable is said to be reliable, if the results of $\alpha>0.70$ are reliable and the results of $\alpha<0.70$ are not reliable.

Based on the results of the validity test, all statements in the three variables in this study were declared valid because $r$ count $>0.361$. Then, the reliability test results showed that the first independent variable (X1) of knowledge, showed a Cronbach's Alpha value of 0.911. While the second independent variable (X2) attitudes, showing a Cronbach's Alpha value of 0.988. While the third independent variable (X3) tends to behave, showing Cronbach's Alpha of 0.954.

These three numbers indicate that all three variables in this study are reliable because they are greater than 0.7. The results of the normality test that have been carried out by displaying the results using a scatter plot show that the three variables tested were normally distributed. Then the test continues with testing with the $t$ statistic that is independent sample t test.

The t-Test is intended to see the significance of the influence of individual independent variables on the dependent variable, assuming the other independent variables are constant. The hypothesis in this test is:

$\mathrm{H} 0: \beta \mathrm{i}=0$ (it means that there is no significant effect between the independent variables on the dependent variable).

Ha: $\beta \mathrm{i}>0$ (it means there is a significant influence between the independent variables on the dependent variable).

$\beta$ is the coefficient of the 1 st independent variable and constant, while $\beta$ is the value of the hypothesis parameter. Usually $\beta$ (regression coefficient or determination) is considered equal to zero or there is no influence between the independent variables on the dependent variable. Terms of acceptance or rejection of the $\mathrm{H} 0$ hypothesis are as follows:

Reject H0 if Sig (One tailed) $<0.05$

Reject Ha if Sig (One tailed) $\geq 0.05$

Table 1

Test Results Comparison of Pretest-Posttest knowledge of Experimental Group Knowledge (Independent Samples Test)

\begin{tabular}{|c|c|c|c|c|c|}
\hline $\begin{array}{l}\text { Levene's Test } \\
\text { for Equality } \\
\text { of Variance }\end{array}$ & \multicolumn{5}{|c|}{ t-test for Equality of Means } \\
\hline \multirow[t]{2}{*}{$\mathrm{F}$} & \multirow[t]{2}{*}{ df } & \multirow[t]{2}{*}{$\begin{array}{l}\text { Sig. } \\
(2- \\
\text { tailed })\end{array}$} & \multirow[t]{2}{*}{$\begin{array}{c}\text { Mean } \\
\text { Difference }\end{array}$} & \multirow[t]{2}{*}{$\begin{array}{l}\text { Std. Error } \\
\text { Difference }\end{array}$} & $\begin{array}{l}\text { 95\% Confidence } \\
\text { Internal of the } \\
\text { Difference }\end{array}$ \\
\hline & & & & & Lower \\
\hline
\end{tabular}




\begin{tabular}{llllllllll}
\hline $\begin{array}{l}\text { Equal Variances } \\
\text { Assumed }\end{array}$ &, 379 &, 543 & $-1,644$ & 28 &, 111 & $-2,667$ & 1,622 & $-5,990$ &, 656 \\
\hline $\begin{array}{l}\text { Equal Variances } \\
\text { not Assumed }\end{array}$ & & $-1,644$ & 26,933 &, 112 & $-2,667$ & 1,622 & $-5,996$ &, 662 \\
\hline
\end{tabular}

Based on the table 1, it can be seen that Sig $>0.05$, the initial conditions of the experimental group's knowledge before and after being given a video campaign have not changed significantly.

Table 2

Test Results Comparison of Pretest-Posttest Knowledge of Controlled Group (Independent Samples Test)

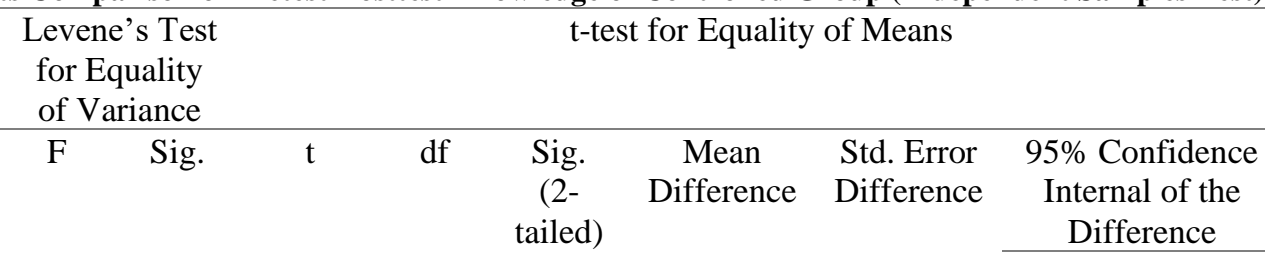

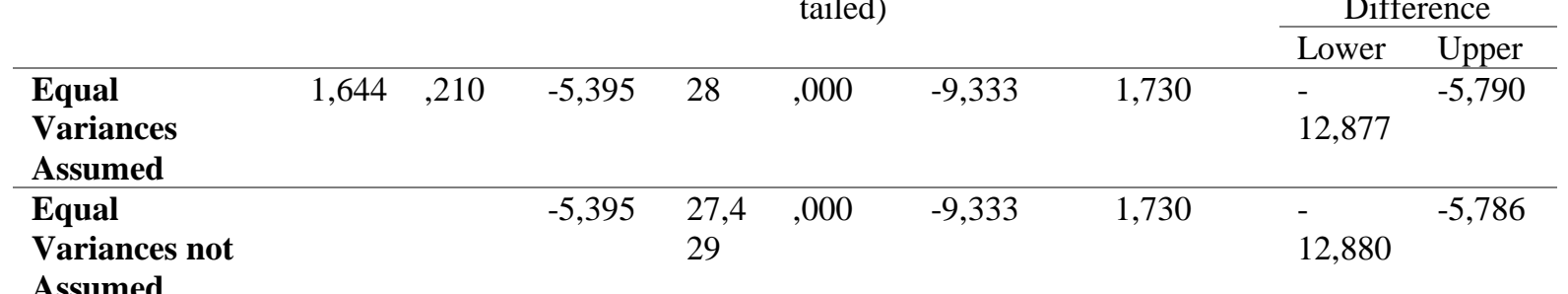

Based on the table 2, it can be seen that Sig> 0.05, the initial conditions of the controlled group's knowledge before and after being given a video campaign have changed significantly.

Table 3.

Test Results of Pretest-Posttest Attitude of Experimental Groups (Independent Samples Test)

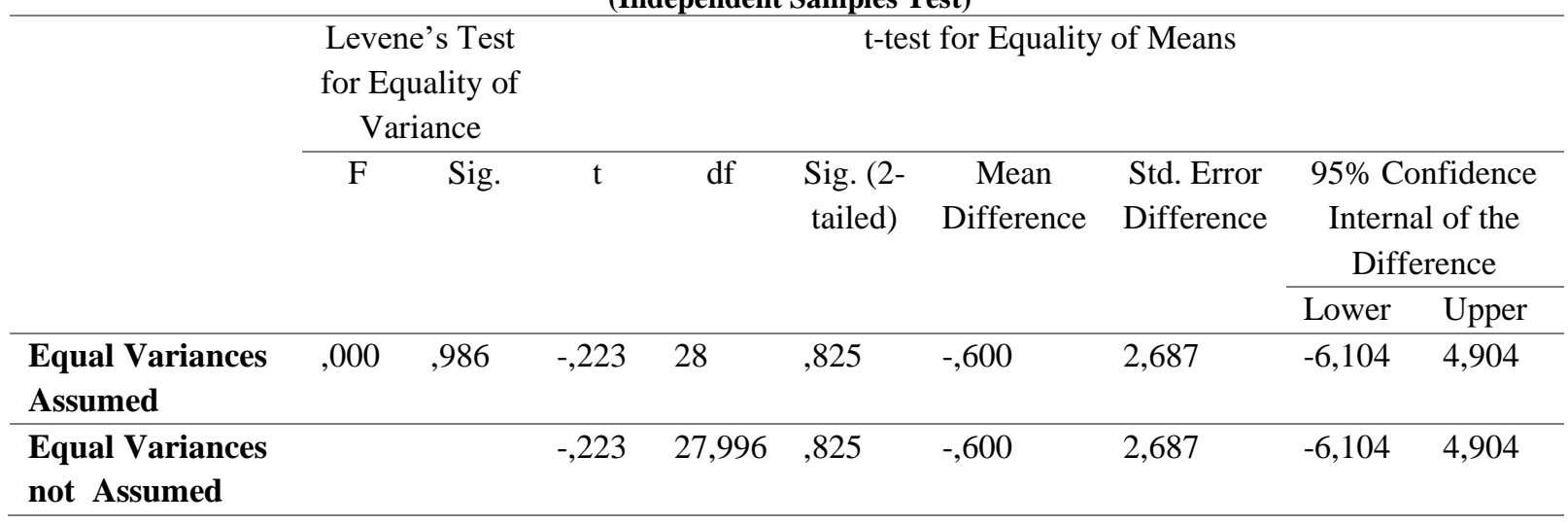

Based on the table 3, it can be seen that Sig> 0.05, the initial conditions of the experiment group's attitude before and after being given a video campaign have not changed significantly. 
Table 4

Test Results of Pretest-Posttest Attitude of Controlled Groups (Independent Samples Test)

\begin{tabular}{|c|c|c|c|c|c|c|c|c|c|}
\hline & \multicolumn{2}{|c|}{$\begin{array}{l}\text { Levene's } \\
\text { Test for } \\
\text { Equality of } \\
\text { Variance }\end{array}$} & \multicolumn{7}{|c|}{ t-test for Equality of Means } \\
\hline & \multirow[t]{2}{*}{$\mathrm{F}$} & \multirow[t]{2}{*}{ Sig. } & \multirow[t]{2}{*}{$\mathrm{t}$} & \multirow[t]{2}{*}{ df } & \multirow{2}{*}{$\begin{array}{l}\text { Sig. } \\
(2- \\
\text { tailed } \\
\quad)\end{array}$} & \multirow[t]{2}{*}{$\begin{array}{c}\text { Mean } \\
\text { Difference }\end{array}$} & \multirow[t]{2}{*}{$\begin{array}{l}\text { Std. Error } \\
\text { Difference }\end{array}$} & \multicolumn{2}{|c|}{$\begin{array}{l}\text { 95\% Confidence } \\
\text { Internal of the } \\
\text { Difference }\end{array}$} \\
\hline & & & & & & & & Lower & Upper \\
\hline $\begin{array}{l}\text { Equal Variances } \\
\text { Assumed }\end{array}$ & ,234 & ,632 &,- 802 & 28 & ,429 & $-2,600$ & 3,242 & $-9,242$ & 4,042 \\
\hline $\begin{array}{l}\text { Equal Variances } \\
\text { not Assumed }\end{array}$ & & &,- 802 & 27,895 & ,429 & $-2,600$ & 3,242 & $-9,243$ & 4,043 \\
\hline
\end{tabular}

Based on the table 4, it can be seen that $\operatorname{Sig}>0.05$, the initial conditions of the controlled group's attitude before and after being given a video campaign have not changed significantly.

Table 5

Test Results of Pretest-Posttest Comparison of Experimental Group Behavior Intention Levene's Test for t-test for Equality of Means Equality of Variances

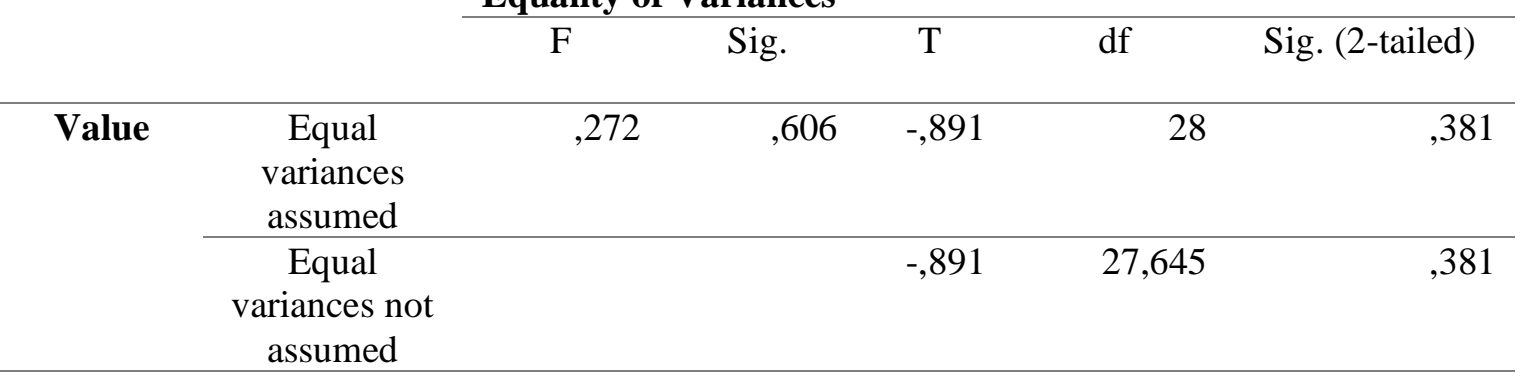

Based on the table 5, it can be seen that Sig> 0.05, the initial conditions of the experiments group's behavior intention before and after being given a video campaign have not changed significantly.

Table 6

Test Results of Pretest-Posttest Comparison of Controlled Group Behavior Intention

\begin{tabular}{ccccccc}
\hline & & \multicolumn{2}{c}{$\begin{array}{c}\text { Levene's Test for } \\
\text { Equality of Variances }\end{array}$} & \multicolumn{3}{c}{ t-test for Equality of Means } \\
\cline { 3 - 7 } Value & F & Sig. & t & df & Sig. (2-tailed) \\
\hline $\begin{array}{c}\text { Equal } \\
\text { variances } \\
\text { assumed }\end{array}$ &, 026 &, 872 &,- 567 & 28 &, 575 \\
\hline $\begin{array}{c}\text { Equal } \\
\text { variances not }\end{array}$ & & & & & & \\
\hline
\end{tabular}


assumed

Based on the table 6, it can be seen that Sig $>0.05$, the initial conditions of the controlled group's behavior intention before and after being given a video campaign have not changed significantly.

Based on the results of the $\mathrm{t}$ - Test, it showed that the knowledge variable (X1) (Y1) of the experimental group showed 0.111. While the knowledge variable (X1) (Y1) control group showed 0,000 . The attitude variable (X2) (Y2) of the experimental group showed 0.818 . While the attitude variable (X2) (Y2) control group showed 0.375 .

The behavioral tendency variable (X3) (Y3) of the experimental group showed 0.381. While the behavioral tendency variable (X3) (Y3) the control group showed 0.575. From these results, it is seen that the attitude variable (X2) (Y2) of the experimental group did not change after seeing the prevention campaign video because it was smaller than 0.05 while the other variables experienced a change after seeing the prevention campaign video because it was greater than 0.05 .

Based on the results of the research, it can be said that there is no change in knowledge, attitudes and behavioral tendencies in preventing cervical cancer among students in North Jakarta after getting action / experiments through video counseling, both in the work group / experiment and the control group.

This can be understood that the present information is wide open to be accessible to anyone in this world. Both through formal and non-formal education. This is because it is so extraordinary that the information and communication media that are growing and developing today are like social media, besides the mass media which can increasingly provide alternative information to the general public.

Teen age is the age of identity search. Besides them many who have a very high curiosity, they are the fastest generation to accept all innovations. Their awareness to have a healthy lifestyle also tends to increase now. Also included in being aware of the diseases that are typically possessed by women such as cervical cancer, uterine cancer, breast cancer, and cysts.

The next assumption is that it was alleged that the contents of the information extension video were general in nature and not detailed enough. The information presented is of a general nature which is apparently commonly found in public talks and in discussions on social media and in the mass media. Thus, respondents feel that the information in the video is not something "new" in nature.

\section{CONCLUSION}

The level of knowledge of the experimental group with a significant probability value of $0.111>0.05$ was not easily influenced by video campaigns showing cervical cancer prevention. While the level of knowledge of the control group with a significance value of $0.000>0.05$ can very easily be influenced by a video campaign for cervical cancer prevention.

The attitude of the experimental group with a significance value of between 0.825> 0.05 and the attitude of the control group with a significance value of $0.429>0.05$ both did not get a significant effect from the video show of cervical cancer prevention campaign. 
Similarly, Video campaigns for cervical cancer prevention did not have a significant effect on the propensity to behave in the experimental group with a significance probability value of $0.381>0.05$. Meanwhile, the cervical cancer prevention campaign video also did not have a significant effect on the attitude level of the control group with a significance probability value of $0.575>0.05$.

The reproductive counseling video also did not affect the tendency to behave well in the experimental and control groups. It is suspected that the knowledge, attitudes and behavioral tendencies of female students are quite good in preventing cervical cancer or there is a possibility that the contents in the video are indeed ineffective in conveying messages of prevention of cervical cancer prevention.

\section{ACKNOWLEDGEMENT}

I would like to thank Prof. Husein Umar, Head of Research and Development, Institut Bisnisdan Informatika Kwik Kian Gie. I also would like to thank all of respondents and sponsored for this research

\section{REFERENCES}

Ajzen, I \& Fishbein, M. (1980). Understanding attitudes and predicting social behavior. Englewood Cliffs, NJ: Prentice-Hall

Becker, E. A., \& Gibson, C. C. (1998). Fishbein and Ajzen's theory of reasoned action: Accurate prediction of behavioral intentions for enrolling in distance education courses. Adult Education Quarterly, 49(1), 43-55.

Cohen, P. A., Jhingran, A., Oaknin, A., \& Denny, L. (2019). Cervical cancer. The Lancet, 393(10167), 169-182.

Jenkins, C. N., McPhee, S. J., Bird, J. A., Pham, G. Q., Nguyen, B. H., Nguyen, T.,\& Davis, T. B. (1999). Effect of a media-led education campaign on breast and cervical cancer screening among Vietnamese-American women. Preventive medicine, 28(4), 395-406.

Kanker Serviks Pembunuh Banyak Wanita.(Cervical cancer kills many women) (2019). Retrieved July $12^{\text {th }}, 2020$ from

http://kumpulan.info/sehat/artikel-kesehatan/237-kanker-serviks-leher-rahimpembunuh-wanita.html.

Kasus Kanker Serviks di Indonesia Tertinggi di Dunia.( The second highest case of cervical cancer in the world). (2017). Retrieved July $12^{\text {th }}, 2020$ from http://www.harnas.co/2017/03/15/indonesia-tertinggi-kedua-di-dunia-soal-kankerserviks-

Kementerian Kesehatan Republik Indonesia. (2019). Cerdik tanggulangi kanker, Retrieved July $12^{\text {th }}, 2020$ from https://www.kemkes.go.id/article/view/19082000006/cerdiktanggulangi-kanker.html

KICKS. (2017). Koalisi Indonesia cegah kanker serviks, Retrieved July 12 $2^{\text {th }}, 2020$ from https://cegahkankerserviks.org/tentangkicks\#: :text=KICKS, serviks\%20yang\%20efektif\%20di\%20Indonesia.

Kuswandoro, Wawan. (2015). Teori Fungsionalisme Struktural Parsons, Lecture.ub.ac.id. Retrieved July $12^{\text {th }}, 2020$ from 
http://wkwk.lecture.ub.ac.id/2015/10/teori-fungsionalisme-struktural-parsons/.

Love, G. D., Mouttapa, M., \& Tanjasiri, S. P. (2009). Everybody's talking: using entertainment-education video to reduce barriers to discussion of cervical cancer screening among Thai women. Health education research, 24(5), 829-838.

Mewaspadai Kanker Serviks Penyakit Yang Merenggut Julia Perez. (Watch out for cervical cancer that claimed Julia Perez). (2017). Retrieved July 12 $2^{\text {th }}, 2020$ from https://kumparan.com/@kumparansains/mewaspadai-kanker-serviks-penyakit-yangmerenggut-julia-perez.

Morissan. (2014). Teori Komunikasi Individu Hingga Massa. Jakarta: Kencana Prenadamedia Group.

Mulyana, D. (2005). Ilmu Komunikasi Suatu Pengantar. Bandung : PT Remaja Rosdakarya

Ngoma, M., \& Autier, P. (2019). Cancer prevention: cervical cancer. ecancermedicalscience, 13.

Rakhmat, J., \& Subandi, I.S. (2017). Metode penelitian komunikasi: dilengkapi contoh analisis statistik. Remaja Rosdakarya.

Ratnasari, E.D. (2017). 'Kampanye' Bahaya Kanker Serviks Selebriti di Media Sosial. CNN Indonesia, Retrieved July $12^{\text {th }}, 2020$ from https://www.cnnindonesia.com/gayahidup/20170814225119-255-234765/kampanye-bahaya-kanker-serviks-selebriti-dimedia-sosial

Susanti, H. D., Setyowati, S., \& Afiyanti, Y. (2017, October). Factors Affecting Women's Motivation to Perform a Cervical Cancer Screening Test. In Health Science International Conference (HSIC 2017). Atlantis Press.

Wahyono, Budi. (2014). Teori Perilaku Yang Direncanakan (Theory Of Planned Behavior). Retrieved July 12 $2^{\text {th }}, 2020$ from http://www.pendidikanekonomi.com/2014/08/teoriperilaku-yang-direncanakan-theory.html

\section{ABOUT THE AUTHOR}

Imam Nuraryo is a lecturer at Department of Communication, Institut Bisnis dan Informatika Kwik Kian Gie, Indonesia. He teaches several subjects such as Psychology of Communication, Communication Research Methodology, and Interpersonal Skills. His research interests are media and communication, especially Broadcasting Industry Management, Investigating Journalism, Risk Communication, and Public Opinion. Email: imam@kwikkiangie.ac.id ; imam.nuraryo@gmail.com 